\title{
Antipromastigote and cytotoxic activities of some chemical constituents of Hypericum lanceolatum Lam. (Guttifereae)
}

Theodora K. Kowa ${ }^{1,2^{*}}$, Lauve R. Y. Tchokouaha ${ }^{1,3}$, Jean Noel Nyemb ${ }^{4}$, Hippolyte K. Wabo ${ }^{2}$, Alembert T. Tchinda ${ }^{1}$, Regina Appiah-Opong ${ }^{5}$, Gabriel A. Agbor ${ }^{1}$, Pierre Tane ${ }^{2}$, Michel Frederich ${ }^{6}$

${ }^{1}$ Laboratory of Phytochemistry, Centre for Research on Medicinal Plants and Traditional Medicine, Institute of Medical Research and Medicinal Plants Studies, Yaounde, Cameroon.

${ }^{2}$ Laboratory of Natural Products Chemistry, Department of Chemistry, Faculty of Science, University of Dschang, Dschang, Cameroon.

${ }^{3}$ Department of Parasitology, Noguchi Memorial Institute for Medical Research NMIMR , College of Health Sciences CHS , University of Ghana, Legon LG581, Ghana.

${ }^{4}$ Laboratory of Chemistry, Department of Chemistry, Faculty of Science, University of Ngaoundere, Ngaoundere, Cameroon.

${ }^{5}$ Department of Clinical Pathology, NMIMR, CHS, University of Ghana, Legon LG581, Ghana.

${ }^{6}$ Laboratory of Pharmacognosy, Center for Interdisciplinary Research on Medicines, CIRM, University of Liege, 4000 Liege, Belgium.

\section{ARTICLE INFO \\ Received on: 23/07/2019 \\ Accepted on: 13/10/2019 \\ Available online: 03/01/2020}

\section{Key words:}

Guttiferae; hypericum

lanceolatum, benzophenone, antipromastigote activity, cytotoxicity.

\begin{abstract}
Phytochemical investigation of the ethanol extract of the stem bark of Hypericum lanceolatum Lam. (Guttifereae) afforded eight known compounds including 2,2',5,6'-tetrahydroxybenzophenone (1), 5-hydroxy-3-methoxyxanthone (2), 3-hydroxy-5-methoxyxanthone (3), betulinic acid (4), hydroquinone (5) 6,7-dihydroxy-1,3-dimethoxyxanthone (6), calophyllumin A (7), and 1,3,5,6-tetrahydroxy-4-prenylxanthone (8). Compound $\mathbf{1}$ was submitted to acetylation reaction to give 5-acetoxy-2,2',6'-trihydroxybenzophenone (9), a new hemisynthetic derivative. Compounds $\mathbf{5}$ and 8 were isolated for the first time from this plant. The structures were established by extensive analysis of their mass spectrometry and nuclear magnetic resonance (NMR) spectroscopic data and comparison with those from the literature. The isolated compounds $(\mathbf{1}, \mathbf{2}, \mathbf{4}, \mathbf{5}$, and $\mathbf{8})$ and the derivative of benzophenone (9) were tested for their antipromastigote and cytotoxic activities against visceral leishmaniasis parasite Leishmania donovani and macrophage RAW 264.7 cell line, respectively. Compound 9 was the most active with an $\mathrm{IC}_{50}$ value of $6.1 \mu \mathrm{g} / \mathrm{ml}$, while compounds $\mathbf{1}, \mathbf{2}, \mathbf{4}$, and 8 were moderately active with $\mathrm{IC}_{50}$ values ranging from 11.4 to $34.8 \mu \mathrm{g} / \mathrm{ml}$ against $L$. donovani and were not cytotoxic except compound $\mathbf{5}$ that was very toxic and not active. The findings of the present study suggested that compounds $\mathbf{1}$, $\mathbf{2}, \mathbf{4}$, and $\mathbf{8}$ could be considered as a potential source of therapeutic medicine for the treatment of leishmaniasis.
\end{abstract}

\section{INTRODUCTION}

Leishmaniasis is a noncontagious, infectious-parasitic disease, caused by protist parasites of the genus Leishmania and transmitted by the bite of a female phlebotomine sand fly. These neglected diseases are considered as a serious health concern, which is occurring in Africa, Asia, Southern Europe,

\section{*Corresponding Author}

Theodora K. Kowa, Laboratory of Phytochemstry, Centre for Research on Medicinal Plants and Traditional Medicine, Institute of Medical Research and Medicinal Plants Studies, Yaounde, Cameroon.

E-mail: kothera81@yahoo.fr and Latin America (WHO, 2016). According to the World Health Organization records, around 12 million people are infected with leishmaniasis, and 350 million people are considered at risk of acquiring an infection (WHO, 2016). The disease is spreading at an alarming rate with an estimated 2 million new cases occurring annually (WHO, 2016). Leishmaniasis can be categorized into different forms such as mucocutaneous leishmaniasis (MCL), visceral leishmaniasis, and cutaneous leishmaniasis (CL) (Alves et al., 2003). Reported studies revealed about 0.5 and 1.5 million cases of visceral and CL, respectively (Ejazi and Ali, 2013; Shah et al., 2014). Chemotherapy remains the mainstay for the control of leishmaniasis, as effective vaccines have not been developed (Den Boer et al., 2011; Kedzierski, 2011). Available drugs based 
on pentavalent antimonial as sodium stibugluconate (Pentostam) and meglumine antimoniate (Glucantime) are the current treatment (Rodriguez et al., 2015). However, these limited synthetic drugs require long-term treatments are of high toxicity with severe side effects, high cost, and face severe resistance associated with therapeutic failures (Duthie et al., 2012; Essid et al., 2015). This situation underlines the urgent need to search for new agents for the treatment of leishmaniasis. In recent years, the use of medicinal plants as an alternative for leishmaniasis treatment is quite common in endemic areas (Bahmani et al., 2015).

The genus Hypericum belongs to the Guttiferae family and comprises about 400 species throughout the world except the deserts and low-altitude areas of tropical regions (Lewis, 2003; Meseguer and Sanmartin, 2012). In Cameroon, Hypericum genus is represented by six species including Hypericum lanceolatum Lam., which is a small shrub occurring in mountainous region of West Cameroon (Hutchinson and Dalziel, 1963). In traditional medicine, the leaves of the plant are extracted with palm wine and used for the treatment of skin infections, epilepsies, and tumors, while the roots are boiled in water and used to treat venereal diseases, gastrointestinal disorders, and infertility (Focho et al., 2009). Diverse compounds have been isolated from this genus, including xanthones (Tanaka and Takaishi, 2006), naphtodianthrones, anthraquinones (Yu, 1998), flavonoids (Evangelos et al., 2007; Yu, 1998), phenolics acid (Ming-Jaw et al., 2004), benzophenones (Tanaka et al., 2004), xantholignoids (Iinuma et al., 1996), triterpenes (Seabra et al., 1992), essential oils (Vera et al., 1996), and prenylated derivatives of phloroglucinol (Bruneton, 1999). Previous phytochemical investigations of $H$. lanceolatum revealed the presence of benzophenones, xantholignoids, triterpenes, xanthones, steroids (Wabo et al., 2012), essential oils (Vera et al., 1996), phloroglucinols (Fobofou et al., 2016), anthraquinone derivatives, and flavonoids (Yu, 1998). Moreover, reviews have reported the antimicrobial (Tchakam et al., 2012) and antiplasmodial activities of H. lanceolatum (Zofou et al., 2011). In this work, both in vitro antileishmanial activity and cytotoxicity effect of some constituents from $H$. lanceolatum leaves were evaluated. Furthermore, the hemisynthetic derivative was also evaluated against Leishmania donovani promastigote and macrophage RAW 264.7 cell line.

\section{MATERIALS AND METHODS}

\section{General experimental procedures}

Mass spectral data [Electron impact ionization mass spectroscopy (EIMS)] were recorded on a Finnigan MAT-95 spectrometer $(70 \mathrm{eV})$ with perfluorkerosine as reference substance for high-resolution electrospray ionization time-of flight mass spectrometry (HR-ESI-TOF-MS) (Japan). Melting points of the isolated compounds were determined using an Electrothermal IA9000 Series digital melting-point apparatus (Bibby scientific, Great Britain) and were uncorrected. Ultraviolet and visible spectra were recorded in $\mathrm{MeOH}$ at $25^{\circ} \mathrm{C}$ using a Kontron Uvikon spectrophotometer. The infrared (IR) spectra were measured on a Perkin Elmer 1750 FTIR spectrometer. The nuclear magnetic resonance (NMR) spectra were measured on Bruker 300, 500, and $600 \mathrm{MHz}$ NMR Avance II spectrometers equipped with cryoprobe, with TMS as an internal reference. Chemical shifts were recorded in $\delta(\mathrm{ppm})$, and the coupling constants $(J)$ are in hertz (Hz). Silica gel $60 \mathrm{~F}_{254}$ (70-230; Merck; Darmstadt, Germany) was used for column chromatography. Precoated silica gel Kieselgel $60 \mathrm{~F}_{254}$ plates $(0.25 \mathrm{~mm}$ thick) were used for thin-layer chromatography (TLC), and spots detected by spraying with $50 \%$ sulfuric acid $\left(\mathrm{H}_{2} \mathrm{SO}_{4}\right)$ followed by heating at $100^{\circ} \mathrm{C}$. All solvents were distilled before use.

\section{Sample collection}

The stem bark of $H$. lanceolatum was collected on the Mount Bamboutos flanks (Western Region, Cameroon) in May 2011. The sample identification was confirmed by Mr. Victor Nana, a botanist at the Cameroon National Herbarium in Yaounde, where a voucher specimen was deposited (Voucher No 32356/HNC).

\section{Chemicals and reagents}

RPMI-1640 Medium, Phosphate Buffered Saline, 3-(4,5-dimethylthiazol-2-yl)-2,5-diphenyltetrazolium bromide, and dimethylsulfoxide (DMSO) were obtained from Sigma-Aldrich Co. Fetal bovine serum was purchased from GibcoInvitrogen.

\section{Extraction and isolation}

The dried stem barks of Hypericum lanceolatum (2.0 $\mathrm{Kg})$ were extracted with ethanol $(\mathrm{EtOH})\left(\begin{array}{ll}10 & 1\end{array}\right)$ for three days at room temperature. The resulting extract was then concentrated with the aid of rotavapor to yield $50 \mathrm{~g}$ of crude extract.

This extract was subjected to a silica gel column chromatography and eluted with gradients of $n$-hexane-ethyl acetate (EtOAc) and EtOAc-methanol $(\mathrm{MeOH})$. Forty-five fractions of $400 \mathrm{ml}$ each were collected and combined on the basis of their TLC profiles into four major fractions (F1-F4). Fraction F1 (7 g) was purified on a silica gel column chromatography, eluted with a gradient of $n$-hexane-EtOAc to yield six major sub-fractions (F1AF1F). Betulinic acid (4, $90 \mathrm{mg})$ crystallized from sub-fraction F1C in the mixture of $n$-hexane/EtOAc (9:1). Fraction F2 was purified on a silica gel column chromatography, eluted with a gradient of $n$-hexane-EtOAc to give hydroquinone $(\mathbf{5}, 10 \mathrm{mg})$ and 2,2',5, $6^{\prime}$ tetrahydroxybenzophenone (1, $50 \mathrm{mg})$. Fraction F3 was submitted to a silica gel column chromatography, eluted with gradients of dichloromethane $\left(\mathrm{CH}_{2} \mathrm{Cl}_{2}\right)$-EtOAc and EtOAc-MeOH to yield 5-hydroxy-3-methoxyxanthone (2,9 mg). Fraction F4 was also chromatographed on a silica gel column with increasing mixtures of $n$-hexane-EtOAc. Sub-fractions eluted with $n$-hexane-EtOAc (8:2) were further purified on Sephadex LH-20 using $\mathrm{CH}_{2} \mathrm{Cl}_{2}$ $\mathrm{MeOH}(1: 1)$ to give 6,7-dihydroxy-1,3-dimethoxyxanthone (6, 8.5 $\mathrm{mg}$ ) and 3-hydroxy-5-methoxyxanthone (3,15 mg). Sub-fractions eluted with $n$-hexane-EtOAc (1:1) were rechromatographed on silica gel with $\mathrm{CH}_{2} \mathrm{Cl}_{2}$-EtOAc (7:3) as a solvent system to yield 1,3,5,6-tetrahydroxy-4-prenylxanthone $(\mathbf{8}, 3.5 \mathrm{mg})$ and calophyllumin A (7, $4 \mathrm{mg})$.

\section{In vitro antipromastigote assay}

In vitro antileishmanial activity of compounds was investigated against Leishmania donovani promastigote using 3-[4,5-dimethylthiazol-2-yl]-2,5-diphenyltetrazolium bromide/ phenazinemethosulfate (MTS/PMS, Promega) colorimetric assay (Wong et al., 2014). Briefly, stationary-phase promastigotes 
were seeded into 96-well flat-bottomed microtiter plates at $1.10^{7}$ parasites per well, in a final volume of $100 \mu \mathrm{l}$ medium, and were incubated at $28^{\circ} \mathrm{C}$ with a series of concentrations of compounds, which dissolved in dimethyl sulfoxide and ranging from 12.5 to 200 $\mu \mathrm{g} / \mathrm{ml}$, in triplicate. After 72 hours of incubation, the plates were examined under an inverted microscope to assure the growth of the controls and sterile conditions and $10 \mu \mathrm{l}$ of MTS/PMS was added to each well of the microtiter plate. The plate was then incubated at $28^{\circ} \mathrm{C}$ for color development. After 4 hours of incubation, the optical density (OD) values were read at $490 \mathrm{~nm}$ using an automated microtiter plate reader (TECAN Infinite M200 Pro Plate Reader, Austria). Amphotericin B was used as a positive control, while DMSO was used as a negative control. The experiments were conducted in triplicate. The percent growth inhibition was calculated from the absorbance relative to the negative control, and $50 \%$ cell cytotoxicity $\left(\mathrm{IC}_{50}\right)$ values were determined.

\section{Cytotoxicity assay}

A toxicological assessment was carried out against RAW cell lines using the resazurin assay and has been used to determine the selectivity indices of active compounds as described by Süzgeç-Selçuk et al. (2011). From sub-confluent cultures in $75 \mathrm{~cm}^{2}$ culture flasks, they were trypsinized, counted, suspended in respective medium, and then seeded into triplicate wells of a 96-well plate $\left(100 \mu \mathrm{l}\right.$ per well) at concentrations of $1.10^{5}$ cells per $\mathrm{ml}$ and incubated. Cells were allowed to attach overnight and then treated in triplicate with $10 \mu \mathrm{l}$ per well of 5-fold serially diluted individual compound $(3.2-2,000 \mu \mathrm{g} / \mathrm{ml})$ in the culture medium and incubated for 48 hours. After incubation, $10 \mu \mathrm{l}$ of $2.5 \mathrm{mM}$ of resazurin solution was added to each well and then incubated for 4 hours at $37^{\circ} \mathrm{C}$. Fluorescence signal was measured using the microplate reader at the excitation and emission wavelengths of $530 \mathrm{~nm}$ and $590 \mathrm{~nm}$, respectively. Curcumin was used as a positive control. Experiments were conducted in triplicate. The percent growth inhibition was calculated from the absorbance relative to the negative control, and the concentration of extract that inhibited $50 \%$ of cells $\left(\mathrm{CC}_{50}\right.$ values $)$ was determined. The selectivity index (SI) ratio $\left(\mathrm{CC}_{50}\right.$ for macrophages/ $/ \mathrm{IC}_{50}$ for amastigotes) was used to compare the toxicity of the compounds against the macrophages and their activity against the parasites.

\section{Statistical analysis}

Results were expressed as mean \pm standard deviation (SD). The $\mathrm{IC}_{50}$ and $\mathrm{CC}_{50}$ values were calculated fitting the data as a non-linear regression using a dose-response inhibitory model, in the GraphPad Prism 7.0 program.

\section{RESULTS}

\section{Fractionation and isolation of compounds}

Eight compounds were isolated from crude EtOH extract of stem bark of $H$. lanceolatum and identified as 2,2',5, $6^{\prime}$ tetrahydroxybenzophenone (1) (Wabo et al., 2012), 5-hydroxy3-methoxyxanthone (2) (Wabo et al., 2012), 3-hydroxy-5methoxyxanthone (3) (Wabo et al., 2012), betulinic acid (4) (Wabo et al., 2012), hydroquinone (5) (Muhammad et al., 2017), 6,7-dihydroxy-1,3-dimethoxyxanthone (6) (Wabo et al., 2012), calophyllumin A(7) (Iinuma et al., 1996), and 1,3,5,6-tetrahydroxy- 4-prenylxanthone (8) (Wu et al., 1998) (Fig. 1). Compound 9, namely, 5-acetoxy-2,2',6'-trihydroxybenzophenone, was obtained from the acetylation of 2,2',5,6'-tetrahydroxybenzophenone (1), and its structure was deduced from different mass and NMR techniques. Among these compounds, compound $\mathbf{9}$ was considered as a new compound, additionally, compound $\mathbf{5}$ was isolated from the stem bark of $H$. lanceolatum for the first time. The spectral data of eight compounds were described in detail below, and the structures were shown in Figure 1.

\section{2,2'5,6'-tetrahydroxybenzophenone (1)}

Yellow needles from the mixture of hexane-AcOEt (90:10); m.p $201^{\circ} \mathrm{C}-202^{\circ} \mathrm{C}$; IR (KBr), $v_{\max }\left(\mathrm{cm}^{-1}\right): 3,367,3,265$, 1,637 $(\mathrm{C}=\mathrm{O}), 1,527,1,479 ;{ }^{1} \mathrm{H}$ NMR $\left(600 \mathrm{MHz}\right.$, acetone- $\left.d_{6}\right), \delta_{\mathrm{H}}$ (ppm): 12.70 (1H, 2'-OH), $9.00(1 \mathrm{H}, 2-\mathrm{OH}), 7.68(1 \mathrm{H}, \mathrm{t}, J=8.3$ $\left.\mathrm{Hz}, \mathrm{H}-4^{\prime}\right) ; 7.58(1 \mathrm{H}, \mathrm{d}, J=3.0 \mathrm{~Hz}, \mathrm{H}-6) ; 7.50(1 \mathrm{H}, \mathrm{d}, J=9.0$ $\mathrm{Hz}, \mathrm{H}-4) ; 7.41$ (1H, dd, $J=3.0,9.0 \mathrm{~Hz}, \mathrm{H}-4) ; 6.97$ (1H, dd, $J=$ 8.2, $\left.1.0 \mathrm{~Hz}, \mathrm{H}-5^{\prime}\right), 6.75(1 \mathrm{H}, \mathrm{dd}, J=8.2,1.0 \mathrm{~Hz}, \mathrm{H}-7) ;{ }^{13} \mathrm{C} \mathrm{NMR}$ $\left(150 \mathrm{MHz}\right.$, acetone- $\left.d_{6}\right){ }_{\mathrm{C}}(\mathrm{ppm}): 182.9(\mathrm{C}=\mathrm{O}) ; 162.7\left(\mathrm{C}-2^{\prime}\right) ; 154.9$ (C-2); 157.3 (C-6'); 151.0 (C-5); 137.7 (C-4'); 126.1 (C-4), 120.1 (C-3); 110.5 (C-3'); 109.1(C-6); 109.1 (C-1'); 107.0 (C-5'). EIMS: $\mathrm{m} / \mathrm{z} 228.0413\left(\left[\mathrm{M}-\mathrm{H}_{2} \mathrm{O}\right]^{+}\right.$(calcd for $\left.\mathrm{C}_{13} \mathrm{H}_{8} \mathrm{O}_{4} 228.0423\right)$. According to the literature Wabo et al. (2012).

\section{5-hydroxy-3-methoxyxanthone (2)}

Yellow needles from the mixture of hexane-AcOEt (90:10); m.p $166^{\circ} \mathrm{C}-168^{\circ} \mathrm{C}$; IR (KBr), $v_{\max }\left(\mathrm{cm}^{-1}\right): 3,326 ; 1,641$ $(\mathrm{C}=\mathrm{O}) ; 1,579(\mathrm{C}=\mathrm{C}) ; 1,120 ; 864 ;{ }^{1} \mathrm{H} \mathrm{NMR}\left(600 \mathrm{MHz}, \mathrm{DMSO}-d_{6}\right)$, $\delta_{\mathrm{H}}(\mathrm{ppm}): 10.45(1 \mathrm{H}, 5-\mathrm{OH}), 7.65(1 \mathrm{H}, \mathrm{d}, J=8.4 \mathrm{~Hz}, \mathrm{H}-1) ; 7.60$ $(1 \mathrm{H}, \mathrm{dd}, J=6.4,1.5 \mathrm{~Hz}, \mathrm{H}-8) ; 7.55(1 \mathrm{H}, \mathrm{d}, J=3.0 \mathrm{~Hz}, \mathrm{H}-4) ; 7.46$ $(1 \mathrm{H}, \mathrm{dd}, J=8.4,3.0 \mathrm{~Hz}, \mathrm{H}-2) ; 7.32(1 \mathrm{H}, \mathrm{dd}, J=6.4,1.5 \mathrm{~Hz}, \mathrm{H}-6)$, $7.25(1 \mathrm{H}, \mathrm{t}, J=6.4 \mathrm{~Hz}, \mathrm{H}-7) ; 3.95(3 \mathrm{H}, \mathrm{s}, 3-\mathrm{OMe}) ;{ }^{13} \mathrm{C} \mathrm{NMR}$ (150 MHz, DMSO- $\left.d_{6}\right), \delta_{\mathrm{C}}(\mathrm{ppm}): 175.3$ (C-9); 155.5 (C-3); 150 (C-4a); 146.5 (C-5); 145 (C-10a); 124.4 (C-2), 123.7 (C-7); 121.5 (C-8a); 121.2 (C-9a); 119.8 (C-1); 119.8 (C-6); 115 (C-8); 105.6 (C-4); 56.6 (3H, s, 3-OCH $)$. EIMS; $m / z$ (rel int.): $242[\mathrm{M}]^{+}(100)$; 241 (61); 227 (52); 228 (15); 213 (30); 212 (34); 199 (20); 171 (42); 115 (28). HREIMS: $m / z 242.0413$ ([M] $]^{+}$(calcd for $\mathrm{C}_{14} \mathrm{H}_{10} \mathrm{O}_{4}$ 242.0579). According to the literature Wabo et al. (2012).

\section{3-hydroxy-5-methoxyxanthone (3)}

Yellow needles from the acetone; m.p $284^{\circ} \mathrm{C}-285^{\circ} \mathrm{C}$; IR $(\mathrm{KBr}){ }_{\text {max }}\left(\mathrm{cm}^{-1}\right): 3,218 ; 1,623 ; 1,593 ; 1,500 ; 864 ;{ }^{1} \mathrm{H}$ NMR $(600$ MHz, DMSO- $\left.d_{6}\right), \delta_{\mathrm{H}}(\mathrm{ppm}): 7.71(1 \mathrm{H}, \mathrm{dd}, J=8.1,5.0 \mathrm{~Hz}, \mathrm{H}-8)$; $7.60(1 \mathrm{H}, \mathrm{d}, J=9.1 \mathrm{~Hz}, \mathrm{H}-1) ; 7.49(1 \mathrm{H}, \mathrm{brd}, J=8.2 \mathrm{~Hz}, \mathrm{H}-6)$; $7.47(1 \mathrm{H}, \mathrm{d}, J=3.0 \mathrm{~Hz}, \mathrm{H}-4) ; 7.37(1 \mathrm{H}, \mathrm{t}, J=8.0 \mathrm{~Hz}, \mathrm{H}-7) ; 7.32$ $(1 \mathrm{H}, \mathrm{dd}, J=9.0,2.9 \mathrm{~Hz}, \mathrm{H}-2) ; 3.99(3 \mathrm{H}, \mathrm{s}, 5-\mathrm{OMe}) ;{ }^{13} \mathrm{C} \mathrm{NMR}$ (150 MHz, DMSO- $\left.d_{6}\right), \delta_{\mathrm{C}}(\mathrm{ppm}): 175.8$ (C-9); 154.0 (C-3); 149.0 (C-5); 148.4 (C-4a); 145.8 (C-10a); 124.5 (C-2), 123.5 (C-7); 121.5 (C-8a); 121.1 (C-9a); 119.6 (C-1); 116.3 (C-8); 115.8 (C6); $108.3(\mathrm{C}-4) ; 56.1$ (3H, s, 5- $\left.\mathrm{OCH}_{3}\right)$. EIMS; $m / z$ (rel int.): 242 $\left[\mathrm{M}^{+}\right.$(100), 241 (61), 227 (52). HREIMS: $m / z 243.0650\left([\mathrm{M}+\mathrm{H}]^{+}\right.$ (alcd for $\mathrm{C}_{14} \mathrm{H}_{10} \mathrm{O}_{4}$ 243.6519). According to the literature Wabo et al. (2012).

\section{Betulinic acid (4)}

White powder from the mixture of hexene-EtOAc (90:10); m.p. $319^{\circ} \mathrm{C}-320^{\circ} \mathrm{C}$; IR ( $\left.\mathrm{KBr}\right), v_{\max }\left(\mathrm{cm}^{-1}\right)$ : 3,456 (OH); 


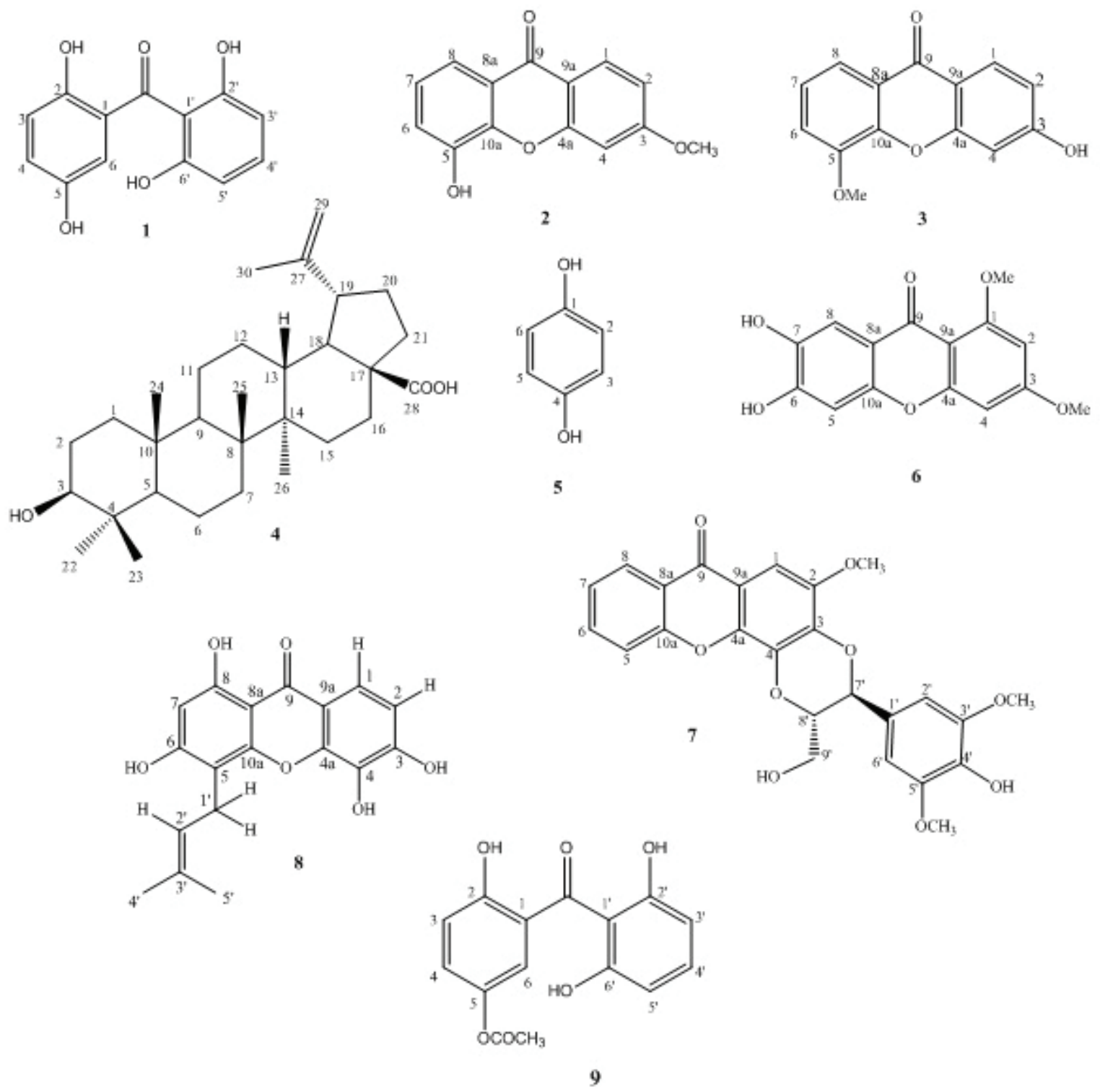

Figure 1. Chemical structure of the isolated compounds (1-9) from H. lanceolatum.

2,$966 ; 1,685(\mathrm{C}=\mathrm{O}) ; 1,627 ; 1,512 ; 1,260 ; 1,175 ; 759 ;{ }^{1} \mathrm{H}$ NMR $(500$ $\left.\mathrm{MHz}, \mathrm{CDCl}_{3}\right), \delta_{\mathrm{H}}(\mathrm{ppm}): 0.60(3 \mathrm{H}, \mathrm{s}, \mathrm{H}-24) ; 0.68(3 \mathrm{H}, \mathrm{s}, \mathrm{H}-25)$; 0.80 (3H, s, H-26); 0.81 (3H, s, H-23); 0.85 (3H, s, H-27); 1.55 $(3 \mathrm{H}, \mathrm{s}, \mathrm{H}-30) ; 3.00(1 \mathrm{H}, \mathrm{m}, \mathrm{H}-3) ; 3.80(1 \mathrm{H}, \mathrm{sl}, \mathrm{H}-29 \mathrm{a}) ; 4.60(1 \mathrm{H}, \mathrm{sl}$, $\mathrm{H}-29 \mathrm{~b}) ;{ }^{13} \mathrm{C}$ NMR $\left(100 \mathrm{MHz}, \mathrm{CDCl}_{3}\right), \delta_{\mathrm{C}}(\mathrm{ppm}): 14.6$ (C-27); 15.3 (C-24); 15.9 (C-26), 16.1 (C-25); 18.0 (C-6), 19.3 (C-30), 20.6 (C11); 25.3 (C-2); 26.7 (C-12), 28.0 (C-23); 29.4 (C-15); 30.3 (C-21); 32.0 (C-16); 34.1 (C-7); 36.9 (C-10); 37.0 (C-22), 38.1 (C-4); 38.4 (C-1); 38.5 (C-13); 40.4 (C-14); 42.1 (C-8); 46.8 (C-19); 49.1 (C18); 50.3 (C-9); 55.2 (C-5); 56.0 (C-17); 78.6 (C-3); 109.7 (C-29); 150.3 (C-20); 179.5 (C-28). EIMS: $m / z 456\left([\mathrm{M}]^{+}\right.$for $\mathrm{C}_{30} \mathrm{H}_{48} \mathrm{O}_{3}$. According to the literature Wabo et al. (2012).

\section{Hydroquinone (5)}

Light brown cristal; m.p. $171^{\circ} \mathrm{C}-172^{\circ} \mathrm{C}$; IR (KBr), $v_{\max }$ $\mathrm{cm}^{-1}: 3,595 ; 2,921 ; 1,590 ; 1,465 ; .{ }^{1} \mathrm{H}$ NMR (500 MHz, CD 3 OD), н (ppm): $6.74(2 \mathrm{H}, \mathrm{dd}, J=6.0,2.0 \mathrm{~Hz}, \mathrm{H}-2$ et $\mathrm{H}-8) ;{ }^{13} \mathrm{C} \mathrm{NMR}$
(125 MHz, CD $30 D), \delta_{\mathrm{C}}$ (ppm): 146.3 (C-1 \& C-4); 120.9 (C-2 \& C-6); 116.4 (C-3 \& C-5). HREIMS: $m / z$ 110.1102 ([M] ${ }^{+}$(calcd for $\mathrm{C}_{6} \mathrm{H}_{6} \mathrm{O}_{2}$ 110.1106). According to the literature Muhammad et al. (2017).

\section{6,7-dihydroxy-1,3-diméthoxyxanthone (6)}

Yellow powder in the acetone; IR $(\mathrm{KBr}), v_{\max } \mathrm{cm}^{-1}$ : 3,330; 1,633 $(\mathrm{C}=\mathrm{O}) ; 1,581 \quad(\mathrm{C}=\mathrm{C}) ;{ }^{1} \mathrm{H} \quad \mathrm{NMR} \quad(400 \mathrm{MHz}$ Pyridine- $\left.d_{5}\right), \delta_{\mathrm{H}}(\mathrm{ppm}): 10.82(1 \mathrm{H}, \mathrm{s}, 7-\mathrm{OH}) ; 10.50(1 \mathrm{H}, \mathrm{s}, 6-\mathrm{OH})$ $7.36(1 \mathrm{H}, \mathrm{s}, \mathrm{H}-8) 6.79(1 \mathrm{H}, \mathrm{s}, \mathrm{H}-5) ; 6.36(1 \mathrm{H}, \mathrm{s}, \mathrm{H}-2) ; 6.31(1 \mathrm{H}$, s, H-4); $3.80\left(3 \mathrm{H}, \mathrm{s}, 1-\mathrm{OCH}_{3}\right) ; 3,61(3 \mathrm{H}, \mathrm{s}, 3-\mathrm{OH}) .{ }^{13} \mathrm{C}$ NMR $(100$ $\mathrm{MHz}$, Pyridine- $\left.d_{5}\right), \delta_{\mathrm{C}}(\mathrm{ppm}): 175.3$ (C-9); 155.5 (C-3); $150(\mathrm{C}-$ 4a); 146.5 (C-5); 145 (C-10a); 124.4 (C-2), 123.7 (C-7); 121.5 (C-8a); 121.2 (C-9a); 119.8 (C-1); 119.8 (C-6); 115 (C-8); 105.6 (C-4); $56.6\left(3 \mathrm{H}, \mathrm{s}, 3-\mathrm{OCH}_{3}\right)$. HREIMS: $m / z 288.0635\left([\mathrm{M}]^{+}\right.$ (calcd for $\mathrm{C}_{15} \mathrm{H}_{12} \mathrm{O}_{6} 288.0634$ ). According to the literature Wabo et al. (2012). 


\section{Calophyllumin A (7)}

Yellow amorphous powder from the mixture $\mathrm{CH}_{2} \mathrm{Cl}_{2}$ $\mathrm{MeOH}(98: 2)$; IR (KBr), $v_{\text {max }}\left(\mathrm{cm}^{-1}\right): 3,161 ; 2,956 ; 1,728 ; 1,647$, 1,$566 ; 1,487 ; 1,103 ; 1,110 ; 918 ;{ }^{1} \mathrm{H}$ NMR (600 MHz, Pyridine- $\left.d_{5}\right)$, $\delta_{\mathrm{H}}(\mathrm{ppm}): 13.01(1 \mathrm{H}, \mathrm{s}, 1-\mathrm{OH}) ; 11.05(1 \mathrm{H}, \mathrm{s}, 3-\mathrm{OH}) ; 8.59(1 \mathrm{H}$, s, 4'-OH), $7.11(1 \mathrm{H}, \mathrm{s}, \mathrm{H}-8) ; 6.77\left(2 \mathrm{H}, \mathrm{s}, \mathrm{H}-2^{\prime}\right.$ et $\left.\mathrm{H}-6^{\prime}\right) ; 6.38(1 \mathrm{H}$, $\mathrm{d}, J=2,0 \mathrm{~Hz}, \mathrm{H}-4) ; 6.19(1 \mathrm{H}, \mathrm{d}, J=2.0 \mathrm{~Hz}, \mathrm{H}-2) ; 5.08(1 \mathrm{H}, \mathrm{t}, J$ $\left.=7.8 \mathrm{~Hz}, 9^{\prime}-\mathrm{OH}\right) ; 5.04\left(1 \mathrm{H}, \mathrm{d}, J=7.8 \mathrm{~Hz}, \mathrm{H}-7^{\prime}\right) ; 4.41(1 \mathrm{H}, \mathrm{m}$, $\left.\mathrm{H}-8^{\prime}\right) ; 3.83\left(3 \mathrm{H}, \mathrm{s}, 7-\mathrm{OCH}_{3}\right) ; 3.75\left(6 \mathrm{H}, \mathrm{s}, 3^{\prime}-\mathrm{OCH}_{3}, 5^{\prime}-\mathrm{OCH}_{3}\right) ; 3.70$ $\left(1 \mathrm{H}, \mathrm{dl}, J=12.7 \mathrm{~Hz}, \mathrm{H}-9^{\prime} \mathrm{a}\right) ; 3.43(1 \mathrm{H}, \mathrm{dd}, J=12.7$ et $4.4 \mathrm{~Hz}$, $\mathrm{H}-9$ b) ; ${ }^{13} \mathrm{C}$ NMR (125 MHz, Pyridine- $\left.d_{5}\right), \delta_{\mathrm{C}}(\mathrm{ppm}): 180.6$ (C-9); 167.3 (C-3); 164.7 (C-1); 158.9 (C-4a); 149.9 (C-3'); 149.8 (C5'); 147.2 (C-7); 142.0 (C-10a); 141.2 (C-6); 136.4 (C-4'); 134.0 (C-5); 126.7 (C-1); 114.0 (C-8a); 106.6 (C-2'); 103.5 (C-6'); 99.7 (C-9a); 97.2 (C-2); 95.3 (C-8); 95.3 (C-4); 80.1 (C-8'); 78.5 (C-7'); $61.4\left(\mathrm{C}-9^{\prime}\right) ; 56.1\left(7-\mathrm{OCH}_{3}\right) ; 56.7 / 56.6\left(3^{\prime}-\mathrm{OCH}_{3}\right)$. HRFABMS: $m / z$ $497.1106\left([\mathrm{M}+\mathrm{H}]^{+}\right.$(calcd for $\left.\mathrm{C}_{25} \mathrm{H}_{22} \mathrm{O}_{11} 497.1084\right)$. According to the literature Iinuma et al. (1996).

\section{1,3,5,6-tetrahydroxy-4-prenylxanthone (8)}

Yellow powder from a mixture of hexane-AcOEt $(9: 1)$; m.p $197^{\circ} \mathrm{C}-198^{\circ} \mathrm{C} ; v_{\max }\left(\mathrm{cm}^{-1}\right): 3,420(\mathrm{OH}) ; 1,652(\mathrm{C}=\mathrm{O}) ; 1,600$; $1,575(\mathrm{C}=\mathrm{C}) ; 1,529 ; 1,465 ; 1,346 ; 1,280 ; 1,182 ; 1,083 ; 811 ;{ }^{1} \mathrm{H}$ NMR (600 MHz, MeOD), $\delta_{\mathrm{H}}(\mathrm{ppm}): 7,54(1 \mathrm{H}, \mathrm{d}, J=8.7 \mathrm{~Hz}$, $\mathrm{H}-8) ; 6.84(1 \mathrm{H}, \mathrm{d}, J=8.7 \mathrm{~Hz}, \mathrm{H}-7) ; 6.18(1 \mathrm{H}, \mathrm{s}, \mathrm{H}-2) ; 5.32(1 \mathrm{H}$, $\left.\mathrm{t}, J=6,9 \mathrm{~Hz}, \mathrm{H}-2^{\prime}\right) ; 3.52\left(2 \mathrm{H}, \mathrm{d}, J=6.9 \mathrm{~Hz}, \mathrm{H}-1^{\prime}\right) ; 1.83(3 \mathrm{H}, \mathrm{s}$, 4'-Me); 1.63 (3H, s, 5'-Me); ${ }^{13} \mathrm{C}$ NMR (150 MHz, MeOD), $\delta_{\mathrm{C}}$ (ppm): 180.7 (C-9); 162.8 (C-3); 160.8 (C-1); 154.7 (C-4a); 151.6 (C-10a); 146.7 (C-6); 132.5 (C-8a), 130.7 (C-3'); 122.2 (C-2'); 115.9 (C-8); 113.3 (C-5); 111.8 (C-7); 106.8 (C-4); 101.6 (C-9a); 96.8 (C-2), 24.5 (3H, s, 4'-Me); 20.9 (2H, s, H-1'); 16.6 (3H, s, 5'Me). EIMS: $m / z 328\left([\mathrm{M}]^{+}\right.$for $\mathrm{C}_{18} \mathrm{H}_{16} \mathrm{O}$ According to the literature Wu et al. (1998).

\section{Chemical modification of compound 1}

2,2',5,6'-tetrahydroxybenzophenone (1) (20 $\mathrm{mg})$ was dissolved in pyridine $(3 \mathrm{ml})$ and acetic anhydride $(3 \mathrm{ml})$ and stirred at room temperature for 24 hours. Ten milliliters of water were added to the mixture and stirred for 30 minutes. Extraction with $\mathrm{CH}_{2} \mathrm{Cl}_{2}$ and purification over a silica gel column with $n$-hexane-AcOEt (7:3) as solvent gave 5-acetoxy-2,2',6'trihydroxybenzophenone (9) (5 mg) (Kopa et al., 2014).Compound 9 was obtained as yellow crystals having a melting point of $246^{\circ} \mathrm{C}-247^{\circ} \mathrm{C}$. Its IR spectrum exhibited strong absorptions at $1,610 \mathrm{~cm}^{-1}(\mathrm{OH})$ and $1,757 \mathrm{~cm}^{-1}$ corresponding to typical vibration bands of a conjugated carbonyl and an ester carbonyl, respectively. Its molecular formula was deduced as $\mathrm{C}_{32} \mathrm{H}_{38} \mathrm{O}_{8}$ from the rigorous analysis of its $1 \mathrm{D}$ and $2 \mathrm{D}$ NMR data jointly with its EIMS spectra, which did not show the peak of the molecular ion but that of a fragment ion at $\mathrm{m} / \mathrm{z} 270\left[\mathrm{M}-\mathrm{H}_{2} \mathrm{O}\right]^{+}$corresponding to the loss of a molecule of $\mathrm{H}_{2} \mathrm{O}$. Another important fragment ion was observed at $m / z 228\left[\mathrm{M}-\mathrm{COMe}-\mathrm{H}_{2} \mathrm{O}+\mathrm{H}\right]^{+}$. The comparison of the molecular weight of this compound with that of $2,2^{\prime}, 5,6^{\prime}-$ tetrahydroxybenzophenone (1) thus reveals a difference in mass of $\mathrm{m} / \mathrm{z} 43$ corresponding to the molar mass of an acetyl unit. 1D and 2D NMR data of compound 9 are almost identical to those of its precursor 2,2',5,6'-tetrahydroxybenzophenone (1). The main differences are observed on the ${ }^{1} \mathrm{H}$ NMR spectrum of compound 9 by the disappearance of the signal of a hydroxyl group in favor of a characteristic methyl signal of an acetyl group at $\delta_{\mathrm{H}} 2.36$ $(3 \mathrm{H}, \mathrm{s})$. This is confirmed by the appearance on the ${ }^{13} \mathrm{C} \mathrm{NMR}$ spectrum of compound 9 of two additional signals at $\delta_{\mathrm{C}} 181.7$ and $\delta_{\mathrm{C}} 21.0$, respectively, corresponding to carbonyl and methyl of an acetyl group. Moreover, when comparing the data from the ${ }^{13} \mathrm{C}$ NMR spectra of the two compounds, we can clearly see that the chemical shifts of carbons $\mathrm{C}-5$ and $\mathrm{C}-4$ have undergone a decrease of $\delta_{\mathrm{C}}-5.2$ and an increase of $\delta_{\mathrm{C}}+4.9$, respectively, and the chemical shift of the $\mathrm{H}-4$ proton evolved toward the weak fields $\left(\delta_{\mathrm{H}}+0.63\right)$. This can only be explained by the presence of the $\mathrm{C}-5$ acetate group, and the fact that the $\mathrm{H}-4$ proton is strongly deshielded by the proximity of the carbonyl group of the acetate moiety. This position of MeO-group at C-5 instead of C-2 or C-2' is confirmed by the HMBC correlation of the methyl protons of the acetyl group with the carbon at C-5 $\left(\delta_{\mathrm{H}} 146.7\right)$.

According to the literature, these different observations allowed us to identify this compound as 5-acetoxy-2,2'6'trihydroxybenzophenone (9), which is a semisynthetic derivative characterized here for the first time.

\section{5-acetoxy-2,2',6'-trihydroxybenzophenone (9)}

Yellow needles; mp $246^{\circ} \mathrm{C}-247^{\circ} \mathrm{C}$; IR (KBr): $v_{\max } \mathrm{cm}^{-1}$ : $3,064,1,757,1,610,1,577,1,485 ;{ }^{1} \mathrm{H}$ NMR (500 MHz, $\left.\mathrm{CDCl}_{3}\right): \delta_{\mathrm{H}}$ $12.70\left(1 \mathrm{H}, \mathrm{s}, 2^{\prime}-\mathrm{OH}\right), 9.00(1 \mathrm{H}, \mathrm{s}, 2-\mathrm{OH}), 7.98$ (1H, s, H-6), 7.61 $\left(1 \mathrm{H}, \mathrm{t}, J=8.3 \mathrm{~Hz}, \mathrm{H}-4^{\prime}\right), 7.50(2 \mathrm{H}, J=8.3 \mathrm{~Hz}, \mathrm{H}-3$ and $\mathrm{H}-4), 6.83$ $\left(1 \mathrm{H}, \mathrm{d}, J=8.3 \mathrm{~Hz}, \mathrm{H}-3^{\prime}\right), 6.81\left(1 \mathrm{H}, \mathrm{d}, J=8.3 \mathrm{~Hz}, \mathrm{H}-5^{\prime}\right), 2.36(3 \mathrm{H}, \mathrm{s}$, $\left.\underline{\mathrm{H}}_{3} \mathrm{COCO}-5\right) ;{ }^{13} \mathrm{C}$ NMR (125 MHz, $\left.\mathrm{CDCl}_{3}\right): \delta_{\mathrm{C}} 181.7(\mathrm{C}=\mathrm{O}), 169.3$ ( $\left.\mathrm{H}_{3} \mathrm{CO} \underline{\mathrm{CO}}\right), 161.9$ (C-6'), 156.3 (C-2'), 153.7 (C-2), 146.7 (C-5), 110.7 (C-4'), 129.7 (C-4), 121.1 (C-1), 107.0 (C-3), 118.0 (C-6), $137.0\left(\mathrm{C}-5^{\prime}\right), 108.7\left(\mathrm{C}-1^{\prime}\right), 119.2\left(\mathrm{C}-3^{\prime}\right), 21.0\left(\mathrm{OCOCH}_{3}\right)$. EIMS:

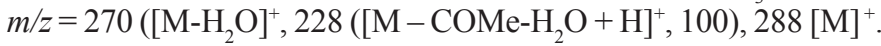

\section{DISCUSSION}

Eight compounds were isolated from the EtOH extract of the stem barks of $H$. lanceolatum, and some of them were evaluated in vitro for their antileishmanial activity against $L$. donovani promastigotes using Amphotericin B as a standard drug (Table 1). 2,2',5,6'-tetrahydroxybenzophenone (1), 5-hydroxy-3methoxyxanthone (2), betulinic acid (4), and 1,3,5,6-tetrahydroxy4-prenylxanthone (8) exhibited moderated activity ( $\mathrm{IC}_{50} 11.36$ $34.81 \mu \mathrm{g} / \mathrm{ml}$ ) and moderate selectivity (SI 2.46-10.47).

Based on the molecular framework of isolated xanthones, the relationship between the in vitro antileishmanial activity and the chemical structure were examined with respect to different functional group therein. Structural comparison between 5-hydroxy-3-methoxyxanthone (2) and 1,3,5,6-tetrahydroxy-4prenylxanthone (8) revealed the presence of three hydroxyl groups and one prenyl in compound $\mathbf{8}$, which are absent in compound $\mathbf{2}$ that contains only one hydroxyl group and one methoxy group, which are absent in compound 8. Azebaze et al. (2008) showed that the prenyl group at position 4 could increase the activity of xanthones. However, the presence of the hydroxyl group in both molecules had an important effect on their antileishmanial activity of compound $\mathbf{8}$.

Betulinic acid (4), a naturally occurring lupane-type triterpene found in many plant species, which has been reported to 
Table 1. Antipromastigote and cytotoxic activities of isolated compounds from the ethanol extract of the stem bark of H. lanceolatum.

\begin{tabular}{|c|c|c|c|}
\hline Compounds & $\begin{array}{c}\mathrm{IC}_{50} \text { on Leishmania donovani } \\
\text { promastigotes }(\mu \mathrm{g} / \mathrm{ml}), \text { Mean } \pm \mathrm{SD}\end{array}$ & $\begin{array}{c}\mathrm{CC}_{50} \text { on RAW cell lines macrophages } \\
(\mu \mathrm{g} / \mathrm{ml}), \text { Mean } \pm \mathrm{SD}\end{array}$ & $\mathbf{S I}=\mathbf{C C}_{50} / \mathbf{C I}_{50}$ \\
\hline 2,2',5,6'-tetrahydroxybenzophenone (1) & $16.2 \pm 1.2$ & $>200$ & $>12.33$ \\
\hline 5-hydroxy-3-methoxyxanthone (2) & $34.8 \pm 1.5$ & $194.2 \pm 0.2$ & 5.6 \\
\hline Betulinic acid (4) & $11.4 \pm 1.1$ & $119 \pm 4.14$ & 10.5 \\
\hline Hydroquinone (5) & $107.9 \pm 2.0$ & $0.1 \pm 1.93$ & 0.001 \\
\hline 1,3,5,6-tetrahydroxy-4-prenylxanthone (7) & $16.4 \pm 1.2$ & $40.6 \pm 6.8$ & 2.5 \\
\hline 5 -acetoxy-2,2',6'-trihydroxybenzophenone (9) & $6.1 \pm 0.8$ & $130.5 \pm 1.9$ & 21.4 \\
\hline Curcumin & nd & $16.8 \pm 0.02$ & nd \\
\hline Amphotericin B & $3.10 \pm 0.13$ & $\mathrm{Nd}$ & nd \\
\hline
\end{tabular}

exhibit anti-HIV-1, antibacterial, antifungal, antiplasmodial, and anti-inflammatory activities (Yogeeswari and Sriram 2005), and has also been reported to inhibit growth of cancer cells, without affecting normal cells (Einzhammer and Xu 2004). Chan-Bacab et al. (2003) have been reported that betulinic acid (4) has the leishmanicidal activity. These results, therefore, confirm the antileishmanial potential of this molecule.

Hydroquinone (5) was previously isolated from the ingredient of many plant-derived products, and an important metabolite of benzene is found to possess strong antiproliferative activity against promastigote forms on Leishmania major and Leishmania tropica in vitro.

2,2'5,6'-tetrahydroxybenzophenone (1) was previously isolated from the stem bark of $H$. lanceolatum and was not showed any activity against Plasmodium falciparum. However, it was not cytotoxic on LLC-MK2 monkey kidney epithelial cells as with on macrophage RAW 264.7 cells line. Acetylation reaction of this compounds gave 5-acetoxy-2,2',6'-trihydroxybenzophenone (9). The structural comparison of compound (1) and compound (9) revealed only the replacement of the hydroxyl group by acetyl group at position $\mathrm{C}-5$. Although the change had an important effect on antileishmanial activity $\left(\mathrm{IC}_{50} 16.2\right.$ to $6.1 \mu \mathrm{g} / \mathrm{ml}$ ), our results showed that the product of acetylation, 5-acetoxy-2,2',6'trihydroxybenzophenone (9) was about 10 times more active than its precursor $\mathbf{1}$. The acetyl group presents at position C-5 is likely to be responsible for most potential antileishmanial activity. Moreover, we also noted that the cytotoxicity increases. The observed differences in bioactivity of the two compounds may only due to the corresponding change in cytotoxicity $\left(\mathrm{CC}_{50}>200\right.$ $130 \mu \mathrm{g} / \mathrm{ml})$. To the best of authors' knowledge, antileishmanial activities of all tested compound have never been reported except for betulinic acid (4).

The cytotoxicity of all these compounds was also assessed (Table 1) on macrophages Raw 264.7 cells line in culture. The results of this assay indicated the selective toxicity by most of the compounds. However, 2,2',5,6'-tetrahydroxybenzophenone (1) showed no signs of cytotoxicity on macrophages $\left(\mathrm{CC}_{50}\right.$ value of $>200$ $\mu \mathrm{g} / \mathrm{ml}$ ), while compound 5-acetoxy-2,2',6'-trihydroxybenzophenone (9) was slightly cytotoxic with a SI of 21.4. Additionally, the less active compound, hydroquinone (5) was cytotoxic at substantially lower concentration $\left(\mathrm{CC}_{50} 0.1132 \mu \mathrm{g} / \mathrm{ml}\right)$ than its antileishmanial concentration $\left(\mathrm{IC}_{50} 107.9 \mu \mathrm{g} / \mathrm{ml}\right)$. All the other compounds showed higher $\mathrm{CC}_{50}$ values compared to their $\mathrm{IC}_{50}$ values.

\section{CONCLUSION}

The present work showed that the ethanol extract contains compounds with different levels of antileishmanial activity. The results derived from this analysis showed that all the evaluated compounds exhibited promising activities with $\mathrm{IC}_{50}$ ranging from 6.1 to $34.8 \mu \mathrm{g} / \mathrm{ml}$. The new semisynthetic derivative 5-acetoxy2,2',6'-trihydroxybenzophenone (9) produced the most potent antileishmanial activity $\left(\mathrm{IC}_{50}=6.1 \mu \mathrm{g} / \mathrm{ml}\right)$ followed by betulinic acid (4) $\left(\mathrm{IC}_{50}=11.4 \mu \mathrm{g} / \mathrm{ml}\right), 2,2^{\prime}, 5,6^{\prime}$-tetrahydroxybenzophenone (1) $\left(\mathrm{IC}_{50}=16.2 \mu \mathrm{g} / \mathrm{ml}\right), 1,3,5,6$-tetrahydroxy-4-prenylxanthone (7) $\left(\mathrm{IC}_{50}=16.4 \mu \mathrm{g} / \mathrm{ml}\right)$, and 5-hydroxy-3-methoxyxanthone (2) $\left(\mathrm{IC}_{50}=34.8 \mu \mathrm{g} / \mathrm{ml}\right)$. However, hydroquinone (5) was weakly active against $L$. donovani promastigotes. There was no significant $(p<0.05)$ difference between the activity of 2,2',5, $6^{\prime}$ tetrahydroxybenzophenone (1) and the one of 1,3,5,6-tetrahydroxy4-prenylxanthone (7). Interestingly, the hemisynthetic derivative 5-acetoxy-2,2',6'-trihydroxybenzophenone (9) exhibited significant activity with an $\mathrm{IC}_{50}$ value of $6.1 \mu \mathrm{g} / \mathrm{ml}$ compared to its precursor $2,2^{\prime}, 5,6^{\prime}$-tetrahydroxybenzophenone (1) with an $\mathrm{IC}_{50}$ of $16.2 \mu \mathrm{g} /$ $\mathrm{ml}$. These findings, therefore, demonstrated the antileishmanial activity of compounds derived from Hypericum lanceolatum. This study constitutes the first report on the antileishmanial activity of chemical constituents from $H$. lanceolatum. It opens perspectives to develop new antileishmanial drug classes from natural compounds, having activity against parasites causing MCL associated to the social stigmatization and disfigurement. This preliminary evaluation using promastigotes must be complemented with an evaluation using intracellular amastigotes in macrophages.

\section{ACKNOWLEDGEMENT}

Authors are grateful to the pharmacognosy team of the University of Liege for their contribution to analysis of some of the compounds. The authors are also grateful to Bill and Melinda Gates Foundation through the postdoctoral fellowship training program in Infectious Diseases at Noguchi Memorial Institute for Medical Research, Ghana (Global Health Grant number OPP52155), for the financial support to carry out biological activities.

\section{FINANCIAL SUPPORT}

None.

\section{CONFLICT OF INTERESTS}

Authors declare that they do not have any competing interests. 


\section{REFERENCES}

Alves LV, Do Canto-Cavalheiro MM, Cysne-Finkelstein L, Leon L. In vitro antiproliferative effects of several diaryl derivatives on Leishmania spp. Biol Pharm Bull, 2003; 26:453-6.

Azebaze AGB, Ouahouo BMW, Vardamides JC, Valentin A, Kuete V, Acebey L, Beng VP, Nkengfack AE, Meyer M. Antimicrobial and antileishmanial xanthones from the stem bark of Allanblackia gabonensis. Chem Nat Compd, 2008; 44:582-7.

Bahmani M, Saki K, Ezatpour BSS, Eftekhari Z, Jelodari M, Mahmoud R-K, Reza S. Leishmaniosis phytotherapy: review of plants used in Iranian traditional medicine on leishmaniasis. Asian Pac J Trop Biomed, $2015 ; 5: 695-701$.

Bruneton J. Pharmacognosie, Phytochimie, Plantes médicinales, 3ème édition, Technique et Documentation Lavoisier, Paris, pp 235-669, 1999.

Chan-Bacab MJ, Balanza E, Deharo E, Munoz V, Duran R, PenaRodriguez LM. Variation of leishmanicidal activity in four populations of Urechites andreuxii. J Ethnopharmacol, 2003; 86:243-7.

Den Boer M, Argaw D, Jannin J, Alvar J. Leishmaniasis impact and treatment access. Clin Microbiol Infect, 2011; 17:1471-7.

Duthie MS, Raman VS, Piazza FM, Reed SG. The development and clinical evaluation of second-generation leishmaniasis vaccines. Vaccine, 2012; 30:134-41.

Einzhammer DA, Xu ZQ. Betulinic acid: a promising anticancer candidate. IDrugs, 2004; 4:359-73.

Ejazi SA, Ali N. Developments in diagnosis and treatment of visceral leishmaniasis during the last decade and future prospect. Exp Rev Anti-Infect Ther, 2013; 11:79-98.

Essid R, Rahali FZ., Msaada K, Sghair I, Hammami M, Bouratbine A, Aoun K, Limam F. Antileishmanial and cytotoxic potential of essential oils from medicinal plants in Northern Tunisia. Ind Crops Prod, 2015; 77:795-802.

Evangelos T, Sjef B, Vassiliki E, Anatassios N, Troganis J. Vervoort J, Loannis P, Gerothanassis P. Identification of the major constituents of Hypericum perforatum by LC/SPE/NMR and/or LC/MS. Phytochem, 2007; 68:383-93.

Fobofou SAT, Franke K, Porzel A, Brandt W, Wessjohann LA. Tricyclic acylphlorolucinols from Hypericum lanceolatum and regioselective synthesis of selancins A and B. J Nat Prod, 2016; 79:743-53.

Focho DA, Nkeng EAP, Lucha CF, Ndam WT, Afegenui A Ethnobotanical survey of plants used to treat diseases of the reproductive system and preliminary phytochemical screening of some species of Malvaceae in Ndop Central Sub-Division, Cameroon. J Med Plan Res, 2009; 3:301-14.

Hutchinson J, Dalziel JM. Pour les Verbenaceae. In: Hepper FN (ed.). Flora of West Tropical Africa. 2nd edition, vol. 2, pp 383-6, 1963.

Iinuma $\mathrm{M}$, Tosa $\mathrm{H}$, Tanaka $\mathrm{T}$, Ito $\mathrm{T}$, Yonemori $\mathrm{S}$, Chelladurai V, Aquil M, Takahashi Y, Naganawa H. Occurrence of xantholignoids in Guttiferous plants. Heterocycles, 1996; 43:1521-7.

Kedzierski L. Leishmaniasis. Human Vaccine, 2011; 7:1204-14.

Kopa TK, Tchinda AT, Tala MF, Zofou D, Jumbam R, Wabo HK, Titanji VPK, Frédérich M, Tan N-H, Tane P. Antiplasmodial anthraquinones and hemisynthetic derivatives from the leaves of Tectona grandis (Verbenaceae). Phytochem Lett, 2014; 8:41-6.

Lewis, LW. Medical botany. John Wiley and Sons, Inc., Hoboken, NJ, p 654, 2003

Meseguer AS, Sanmartín I. Paleobiology of the genus Hypericum (Hyperi-caceae): a survey of the fossil record and its palaeogeographic implications. Anal Jard Bot Madrid, 2012; 69:97-106.

Ming-Jaw D, Yeh-Jeng H, Ray-Ling H, Yun-Lian L. New phenolics principles from Hypericum sampsonii. Chem pharm Bull, 2004; 52:866-9.
Muhammad K, Abdul LK, Liaqat A, Javid H, Muhammad W, Ahmed A-H, Qari MI, Yoon-Ha K, Sang-Mo K B-W Y, In-Jung L. Hydroquinone a novel bioactive compound from plant-derived smoke can cue seed germination of Lettucein. Front Chem, 2017; 30:1-9.

Rodriguez KAF, Amorim LV, Dias CN, Moraes DFC, Carneiro SMP, Carvalho FAA. Syzygium cumini (L) skeels essential oil and its major constituent $\alpha$-pinene exhibit anti-leishmania activity through immunomodulation in vitro. J Ethnopharmacol, 2015; 160:32-40.

Seabra RM, Vascongelos MH, Cruz Costa MA, Alves AC. Phenolic compounds from Hypericum perforatum and Hypericum undulatum. Fitoterapia, 1992; 68:473-4.

Shah NA, Khan MR, Nadhman A. Antileishmanial, toxicity and phytochemical evaluation of medicinal plants collected from Pakistan Biomed Res Int, 2014; article ID 384204, 1-7.

Süzgeç-Selçuk S, Meriçli AH, Güven KC, Kaiser M, Casey RS, Hingley SW, Lalvani A, Tasdemir D. Evaluation of Turkish seaweeds for antiprotozoal, antimycobacterial and cytotoxic activities. Phytother Res, $2011 ; 5: 778-83$

Tanaka N, Takaishi Y, Yasuhiro S, Yuka N, Kenneth BN, Lee K, Honda G, Takeda Y, Olimjon K, Ozodbek A. Prenylated benzophenones and xanthones from Hypericum scabrum. J Nat Prod, 2004; 67:1870-5.

Tanaka N, Takaishi Y. Xanthones from Hypericum chinense. Phytochem, 2006; 67(19):2146-51.

Tchakam PD, Lunga PK, Kowa TK, Wabo HK, Tapondjou AL, Tane P, Kuiate JR. Antimicrobial and antioxidant activities of the extracts and compounds from the leaves of Psorospermum aurantiacum Engl. and Hypericum lanceolatum Lam. BMC Complement Alternat Med, 2012; $12: 1-8$.

Vera RR, Chane-Ming J, Fraise DJ. Essential oil of Hypericum lanceolatum Lam. from Reunion. Rivista Italiana. EPPOS, 1996; 7:639-44.

Wabo HK, Kowa TK, Lonfouo AHN, Tchinda AT, Tane P, Kikuchi H, Frédérich M, Oshima Y. Phenolic Compounds and Terpenoids from Hypericum lanceolatum. Rec Nat Prod, 2012; 6:94-100.

WHO. World Organization Health. Weekly Epidemiology Record, 2016; 91:441-60.

Wong IL, Chan KF, Chen YF, Lun ZR, Chan TH, Chow LM. In vitro and in vivo efficacy of novel flavonoid dimers against cutaneous leishmaniasis. Antimicrob Agents Chemother, 2014; 48:3379-88.

Wu Q-L, Wang S-P, Du L-J, Yang J-S, Xiao P-G. Xanthones from Hypericum japonicum and Hypericum Henryi. Phytochem, 1998; 49:1395-402.

Yogeeswari P, Sriram D. Betulinic acid and its derivatives: a review on their biological properties. Curr Med Chem, 2005; 12:657-66.

$\mathrm{Yu} \mathrm{MO}$. Research of biologically active substances of Hypericum L. species. Farmatsevtichnii Zhurnal, 1998; 5:38-44.

Zofou D, Kowa TK, Wabo HK, Ngemenya MN, Tane P, Titanj VPK. Hypericum lanceolatum (Hypericaceae) as a potential source of new anti-malarial agents: a bioassay-guided fractionation of the stem bark. Malaria J, 2011; 10:1-7.

How to cite this article:

Kowa TK, Tchokouaha LRY, Nyemb JN, Wabo HK, Tchinda AT, Appiah-Opong R, Agbor GA, Tane P, Frederich P. Antipromastigote and cytotoxic activities of some chemical constituents of Hypericum lanceolatum Lam. (Guttifereae). J Appl Pharm Sci, 2020; 10(1):026-032. 